\title{
Progeria-short stature-pigmented nevi syndrome
}

INSERM

\section{Source}

INSERM. (1999). Orphanet: an online rare disease and orphan drug data base. Progeriashort stature-pigmented nevi syndrome. ORPHA:2959

Progeria-short stature-pigmented nevi is a progeroid disorder characterised by low birthweight, short stature, multiple pigmented nevi and lack of facial subcutaneous fat. 